\title{
Season of conception is associated with future survival, fertility, and milk yield of Holstein cows
}

\author{
P. J. Pinedo*1 and A. De Vries† \\ *Department of Animal Sciences, Colorado State University, Fort Collins 80523 \\ †Department of Animal Sciences, University of Florida, Gainesville 32611
}

\begin{abstract}
Environmental influences during different stages of pregnancy can induce lifelong changes in the structure, physiology, and metabolism of the offspring. Our hypothesis was that season of conception (when the offspring was conceived), associated with heat stress conditions at conception and during the initial stages of embryonic development, affects the lifetime performance and survival of the female offspring after birth. The objective was to analyze the association between month of conception and subsequent survival, fertility, and milk yield in cows maintained on dairy farms in Florida, where the climate during the summer is hot and humid but winters are mild. Initial data consisted of 667,104 Dairy Herd Improvement lactation records from cows calving between 2000 and 2012 in 152 herds. Dates of conception were estimated as birth date minus $280 \mathrm{~d}$. The magnitude of heat stress in each herd was quantified by comparing milk yield during summer and winter. Wood's lactation curves were fitted to adjust milk yields for effects of days in milk, and residuals were obtained for each calendar month. A sine function was fitted on the 12 residuals per farm. The difference between the highest and lowest points on the sine function was termed the seasonality index, a measure of the direct effect of heat stress on milk production. Herds were categorized in 3 levels of seasonality [low (seasonality index values less than the 25 th percentile value; $<2.84$ ), medium (values within the interquartile range), and high (values greater than the 75 th percentile value; >5.22)]. Cows were grouped by their month of conception: summer (July-September) and winter (December-February), and comparisons were performed by parity using logistic regression, ANOVA, and survival analysis. Two models were developed. Model A included the complete population of cows $(\mathrm{n}=337,529$ lactation records) conceived in winter or summer.
\end{abstract}

Received January 30, 2017.

Accepted March 30, 2017.

${ }^{1}$ Corresponding author: pablo.pinedo@colostate.edu
Model B included cows $(\mathrm{n}=228,257$ lactation records $)$ that had parent-average genetic information available to be able to correct for farmer's use of lower genetic merit of sires in summer. Other variables included in the models were month and year of calving, age at first calving, and herd. Models were run per parity group $(1,2$, and $\geq 3)$. In both models, age at first calving was lower for cows conceived during winter versus summer. The odds (95\% confidence interval) of survival to a second calving for cows conceived in winter were 1.21 and 1.15 times the odds of survival for cows conceived in summer for models A and B, respectively. Numbers of days from calving to first breeding and from calving to conception were consistently smaller for winter versus summer months of conception across all parity categories. Milk yields (305 d and by $70 \mathrm{~d}$ in milk) were greater for cows conceived in winter versus summer. In conclusion, cows that were conceived in the winter had better subsequent survival and performance than cows that were conceived in the summer. There is evidence that season of conception may have lifelong consequences for the offspring.

Key words: heat stress, conception, performance, survival

\section{INTRODUCTION}

Epidemiological studies in humans and experimental studies using animal models have shown that maternal manipulations, including nutrition and other transient environmental influences, during different stages of pregnancy can induce life-long changes in the structure, physiology, and metabolism of the offspring ( $\mathrm{Wu}$ et al., 2006; Chmurzynska, 2010; Peñagaricano et al., 2013). Moreover, research has suggested that adult disease risk in humans is associated with adverse environmental conditions early in development. Although the mechanisms behind these relationships are unclear, an involvement of epigenetic deregulation has been hypothesized. Heijmans et al. (2008) suggested that individuals who were prenatally exposed to famine showed different levels of DNA methylation compared with unexposed, same-sex siblings. 
It has been suggested that the first stages of mammalian fetal development are determinant for the adult offspring, as dramatic changes in DNA methylation occur that are responsible for cell differentiation of the embryo, determining, in part, phenotype expression in adult life (González-Recio et al., 2012). Some evidence indicates that maternal diet during the different stages of pregnancy can induce physiological and epigenetic changes in fetal tissues in different species, which in turn could have serious implications after birth (Fleming et al., 2012; Lan et al., 2013). During late gestation, malnutrition is related to the lower birth weight of offspring, increased incidence of dystocia, and high mortality and morbidity of neonates (Wu et al., 2006); a link between impaired fetal growth, possibly caused by maternal malnutrition, and reproductive function, involving follicle development, has been also established (Sullivan et al., 2009; Bach, 2012; Dupont et al., 2012).

In dairy cows, other environmental conditions, such as heat stress during late gestation, have also been related to lower birth weight, decreased total plasma protein concentration and hematocrit, and compromised immune function of the newborn (Tao et al., 2012a, 2014; Monteiro et al., 2014). Some studies have reported the potential epigenetic effect on specific production and reproduction traits in dairy cows, with reduced yields for females born to mothers that were lactating while pregnant versus those born to heifers (González-Recio et al., 2012; Gudex et al., 2014). Moreover, 2 recent studies indicated that heat stress at the time of conception of their mothers had an effect on the subsequent milk production of Holstein cows (Brown et al., 2015, 2016).

Summer heat is a significant stressor affecting the dairy cows in many parts of the United States (StPierre et al., 2003). Direct negative effects on milk yield and reproduction are well documented (West, 2003; de Vries and Risco, 2005; Tao and Dahl, 2013).

Estimating the association between exposure to heat stress around time of conception and adult survival and performance of the female offspring is of interest, as summers in Florida easily lead to heat stress in dairy cattle, whereas winters are mild. Our hypothesis was that season of conception, associated with heat stress conditions at conception and during the initial stages of embryonic development, would have a life-long effect on performance and survival after birth. Consequently, the objective of our observational study was to analyze the association between calendar month of conception (associated with heat stress) and subsequent survival, fertility, and milk yield in cows (i.e., offspring) maintained in dairy herds in Florida enrolled in the DHI program.

\section{MATERIALS AND METHODS}

\section{Study Population}

Florida has about 124,000 dairy cows, in herds ranging in size from about 100 to 6,000 cows, with an annual average milk yield per cow of 9,260 kg (Arriola and De Vries, 2016). Most common housing systems include open lot, freestall, grazing, and combinations of these systems. In addition to the use of shade structures, cooling systems for summer months include sprinkling combined with fans (Bucklin et al., 2015).

We analyzed DHI lactation records from 152 herds located in Florida ranging from 100 to 6,632 cows calving per year. A total of 667,104 lactation records of cows born between January 1988 and October 2010 and calving between January 2000 and December 2012 were available. Lactation records were provided by Dairy Records Management Systems (Raleigh, NC) and consisted of date of birth, calving date, parity, test-day milk yields, test-day dates, last reproductive status, date of conception, date of dry off, 305-d milk yield, herd code and state, breeding dates, and reported culling reason and date. Date of conception was estimated as date of birth minus $280 \mathrm{~d}$.

In addition, a subpopulation of cows ( $\mathrm{n}=228,257$ lactation records) had parent-average (PA) genetic data available for multiple traits. These PA were obtained from the August 2015 national genetic evaluation. The PA are estimates of the genetic merit underlying the survival, fertility, and milk yield of the cow based on her sire and dam, but are not affected by the cow's own performance.

Average temperature-humidity indices (THI) in Florida were calculated per calendar month from daily data provided by the National Oceanic and Atmospheric Administration for the years 2007 to 2013, according to the methodology reported by Ferreira et al., (2016). Calculations included the average of the highest and the lowest temperature for each day. The relative humidity was calculated considering average daily temperature and dew point. A THI $>68$ was considered an indication of heat stress (Zimbelman et al., 2009).

\section{Data Edits}

The analyses were restricted to Holstein cows. Lactation records missing parity number or birth or calving dates were removed from the data set. Dates of calving, conception, culling, and last known event were determined for each lactation record. Records that ended with the subsequent calving were considered completed. Records that ended in culling or were censored were 
incomplete. Cows were considered pregnant if their last reported reproductive status was "P" or "E," indicating that pregnancy was reported by the dairy farmer. When the record was not completed and a due date was reported, the conception date was calculated as 280 $\mathrm{d}$ before the provided due date. If a cow did not have a reported due date, but was reported pregnant, then her last breeding date was used as the conception date. The due date was then estimated as conception date plus $280 \mathrm{~d}$. Culling was considered removal from the herd with any disposal code other than dairy purposes. The culling date was the last known reported status date with the status code for culling. Cows culled with the disposal code "dairy purposes" were censored at the date of culling. Records missing a subsequent calving date or a culling event and date were considered censored at the last known event date (Pinedo and De Vries, 2010).

\section{Outcomes of Interest and Explanatory Variables}

Outcome variables included survival to the second calving, days from calving to first breeding, days to conception, milk yield at 70, 120, and 170 DIM, total milk yield over $305 \mathrm{~d}$, and total fat yield over $305 \mathrm{~d}$. The main explanatory variable was the 2 seasons of interest when cows were conceived: summer (date of conception July to September; average THI $=91$ ) and winter (date of conception December to February; average $\mathrm{THI}=63)$.

Control variables included calving month and year, age at first calving, a seasonality index as a measure of heat stress, and herd. Calving month was added as a control variable to separate the effects from heat stress at time of conception from heat stress during lactation.

\section{Measuring Direct Effects of Heat Stress}

The magnitude of heat stress in each herd was evaluated by comparing milk yield during summer and winter. Herds with large differences were assumed to experience more summer heat stress than herds with small differences; for example, as the result of cooling. Because milk yield is dependent on stage of lactation and the herd average stage of lactation may differ throughout the year, we adjusted for stage of lactation effect. Wood's lactation curves (Wood, 1967) were fitted per parity, herd, and year to establish a nonseasonal model of predicted milk yield by DIM. Predicted milk yields at DHI test-days were subtracted from the actual observed milk yields on DHI test day. Residuals were generally negative in the summer and positive in the winter and were assumed to be the direct effects of season. Residuals were measured in kilograms per cow per day.

To measure the amount of seasonality per herd, we fitted a sine function (wave shape) on the residuals across the calendar year per farm using PROC NLIN (release 9.4; SAS Institute Inc., Cary, NC) to measure the level of seasonality for each of the farms. Sine functions have been used previously to quantify seasonality (Stolwijk et al., 1999). The sine function has 3 parameters: the day in the year with the highest milk (typically in the winter), the day in the year with the lowest milk (typically in the summer), and the difference between the highest and lowest milk yield on the sine function. The difference between the highest and lowest points on the sine function (peak-to-peak amplitude) was used as a SI. Herds were categorized in 3 levels of seasonality [low (SI values less than the 25 th percentile value; $<2.84$ ), medium (values within the interquartile range), and high (values greater than the 75 th percentile value; $>5.22$ )], and cows had associated the corresponding seasonality value depending on the herd of origin.

\section{Statistical Analysis}

Parent averages were available for 89,748 cows (228,257 lactation records). Means of PA for 6 traits were calculated by season of conception (Table 1). Group comparisons for continuous outcomes of interest (days from calving to first breeding, days to conception, and milk and fat yield) were performed by parity using ANOVA (PROC GLM in SAS) by use of a Tukey test (LSMEANS statement). The effect of the explanatory variables of interest on the odds and risks of culling and death were estimated by using the logit link in the PROC GLIMMIX procedure. The statistical models included herd as a random effect with the variables of interest and control variables considered as fixed effects. Univariate analyses were used to test the inclusion of each explanatory variable in the final models.

Two models were developed for each outcome of interest. Model A included the complete population of cows ( $\mathrm{n}=337,529$ lactation records) conceived in winter or summer. Model B included the reduced population of cows that had PA values for survival, reproduction, and production traits available. Model B was investigated because of concerns that farmers use semen of lower prices, and hence lower genetic merit, in the summer when conception rates are reduced. Consequently, PA values for traits associated with the corresponding outcome variable were included in the models. Effects with $P \leq 0.20$ were included in the initial multivariate analysis and the final models were obtained through a 
Table 1. Parent averages (averages of cows' parent's predicted transmitting abilities) for 6 traits calculated by the Council on Dairy Cattle Breeding (Beltsville, MD) by season of conception (August 2015)

\begin{tabular}{|c|c|c|c|c|c|}
\hline \multirow[b]{2}{*}{ Genetic trait } & \multicolumn{2}{|c|}{ Conceived in winter } & \multicolumn{2}{|c|}{ Conceived in summer } & \multirow[b]{2}{*}{$P$-value } \\
\hline & LSM & $\mathrm{SE}$ & LSM & $\mathrm{SE}$ & \\
\hline Milk yield & -576 & 1.74 & -639 & 2.69 & $<0.001$ \\
\hline Fat yield & -24 & 0.08 & -26 & 0.12 & $<0.001$ \\
\hline Protein yield & -21 & 0.06 & -22 & 0.09 & $<0.001$ \\
\hline Productive life & -1.07 & 0.006 & -1.13 & 0.009 & $<0.001$ \\
\hline Daughter pregnancy rate & 0.52 & 0.006 & 0.64 & 0.009 & $<0.001$ \\
\hline Net merit dollars & -243 & 0.49 & -254 & 0.76 & $<0.001$ \\
\hline
\end{tabular}

backward elimination procedure. The significance level for inclusion in the final model was set at $P \leq 0.10$ to account for potential confounders affecting both the outcome and the explanatory variables. Season of conception was forced in the final statistical models and interactions between the effect of season of conception and significant variables were considered. Effects were deemed significant when $P \leq 0.05$. In addition, hazard ratios for time to first breeding and conception were calculated for summer versus winter conception by parity using the PHREG procedure of SAS considering calving as the origin of time.

\section{RESULTS}

\section{Descriptive Statistics}

A total of 114,065 and 223,464 lactation records were from cows that were conceived during the summer and the winter, respectively. A detailed distribution of calvings per month is presented in Table 2. From this population of 337,529 lactation records, we found 116,719 (35\%), 90,356 (27\%), and $130,454(38 \%)$ in parity 1,2 , and $\geq 3$, respectively.
Mean (SE) PA for 6 traits by season of conception are presented in Table 1. Parent averages of cows conceived in summer were lower $(P<0.001)$ for milk, fat, protein, productive life, and net merit dollars; PA for daughter pregnancy rate was greater in summer, though.

\section{Reproductive Parameters}

Reproduction statistics were favorable for the cows conceived in the winter. Average age at first calving was $775 \pm 0.96 \mathrm{~d}$ and $766 \pm 0.94 \mathrm{~d}$ for cows conceived in summer and winter, respectively $(P<0.001)$.

For model A (without PA genetics), days from calving to first breeding were $7.0(P<0.001), 5.0(P<$ $0.001)$, and $0.1(P=0.98)$ days shorter for winter versus summer season of conception in parities 1,2 , and $\geq 3$ (Table 3 ). The adjusted hazard ratio for time to first breeding in winter versus summer groups was 1.12 $(P<0.001), 1.06(P<0.001)$, and $1.003(P=0.7)$ in parities 1,2 , and $\geq 3$, respectively. Days to conception were $7(P<0.001), 3(P<0.009)$, and $1(P=0.68)$ d shorter for winter versus summer groups for parities 1,2 , and $\geq 3$, respectively. The adjusted hazard ratio for time to conception in winter versus summer groups

Table 2. Average monthly temperature-humidity index (THI) and monthly distribution of percentage of first, second, and greater calving by season of conception

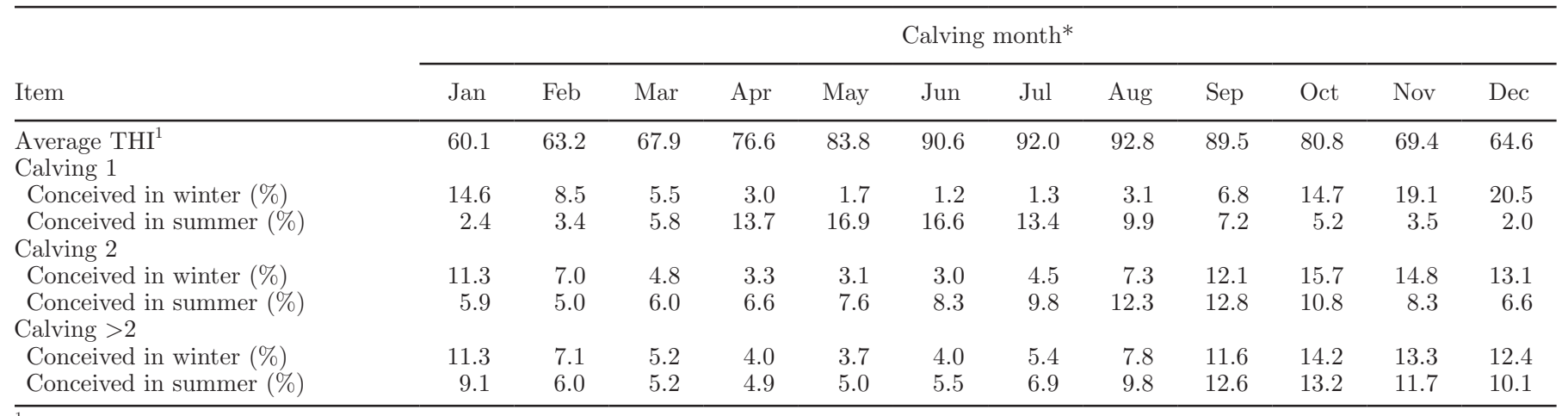

${ }^{1}$ Average THI from 2007 to 2013 for Florida.

$* P<0.001$. 
Table 3. Least squares means (SE) for reproductive variables by season of conception (model A $)^{1}$

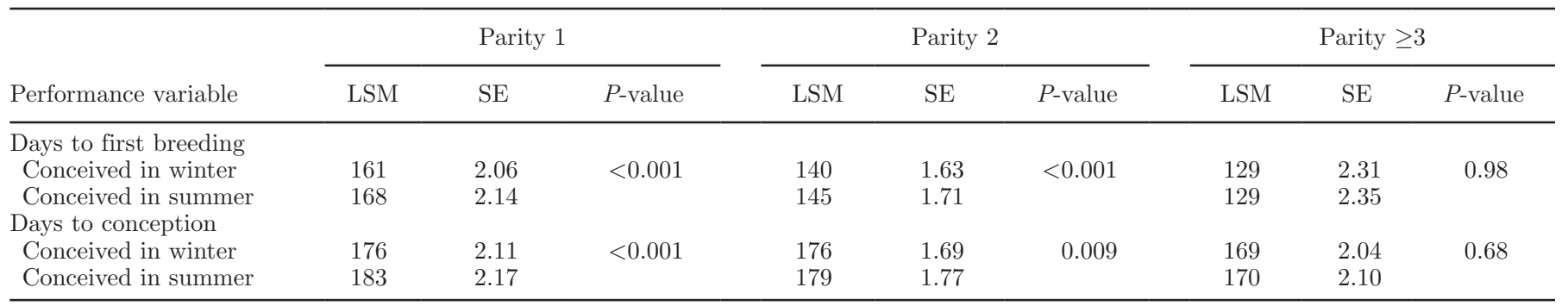

${ }^{1}$ Complete population of cows conceived in summer or winter $(\mathrm{n}=337,529$ lactation records).

was $1.10(P<0.001), 1.04(P<0.001)$, and $0.98(P=$ 0.006 ) for parities 1,2 , and $\geq 3$, respectively.

For model $\mathrm{B}$ (including PA genetics), days from calving to first breeding were $6(P<0.001), 4(P=$ $0.003)$, and $1(P=0.46)$ days shorter for winter versus summer in parities 1,2 , and $\geq 3$, respectively (Table 4 ). The adjusted hazard ratio for time to first breeding in winter versus summer groups was $1.11(P<0.001)$, $1.14(P<0.001)$, and $0.97(P=0.49)$ in parities 1 , 2 , and $\geq 3$, respectively. Days to conception were 7 ( $P$ $<0.001), 4(P=0.005)$, and $1(P=0.46) \mathrm{d}$ shorter for winter versus summer groups for parities 1,2 , and $\geq 3$, respectively. The adjusted hazard ratio for time to conception in winter versus summer groups was $1.03(P$ $<0.001), 1.09(P<0.001)$, and $0.95(P=0.003)$ for parities 1,2 , and $\geq 3$, respectively.

\section{Milk Yield and Milk Fat}

Milk production was generally greater for cows conceived in winter than in summer. For model A, cumulative milk yields were $427(P<0.001), 184(P<0.001)$, and $135(P<0.001) \mathrm{kg} / 305 \mathrm{~d}$ greater for winter versus summer in parities 1,2 , and $\geq 3$, respectively (Table 5 ). Milk yields at 70 DIM were $1.5(P<0.001), 1.3(P<$ $0.001)$, and $1.0(P<0.001) \mathrm{kg} / \mathrm{d}$ greater for winter versus summer for parities 1,2 , and $\geq 3$, respectively. Milk yield at 120 DIM were $2.2(P<0.001), 1.2(P<0.001)$, and $0.8(P<0.001) \mathrm{kg} / \mathrm{d}$ greater for winter versus summer for parities 1,2 , and $\geq 3$, respectively. Milk yield at 170 DIM were $1.2(P<0.001), 0.6(P<0.001)$, and
$0.3(P<0.001) \mathrm{kg} / \mathrm{d}$ greater for winter versus summer for parities 1,2 , and $\geq 3$, respectively. Cumulative fat yields were $13.3(P<0.001), 5.2(P<0.001)$, and 7.0 $(P<0.001) \mathrm{kg} / 305 \mathrm{~d}$ greater for winter versus summer groups for parities 1,2 , and $\geq 3$, respectively.

Results for model B were similar but smaller to those of model A. For model B, cumulative milk yields were $258(P<0.001), 76(P=0.001)$, and $57(P<0.03)$ $\mathrm{kg} / 305 \mathrm{~d}$ greater for winter versus summer in parities 1,2 , and $\geq 3$, respectively (Table 6 ). Milk yield at 70 DIM were $1.6(P<0.001), 0.9(P<0.001)$, and 0.8 $(P<0.001) \mathrm{kg} / \mathrm{d}$ greater for winter versus summer for parities 1,2 , and $\geq 3$, respectively. Milk yield at 120 DIM were $1.6(P<0.001), 0.8(P<0.001)$, and 0.5 $(P<0.001) \mathrm{kg} / \mathrm{d}$ greater for winter versus summer for parities 1,2 , and $\geq 3$, respectively. Milk yield at 170 DIM $(\mathrm{kg} / \mathrm{d})$ were $0.7(P<0.001), 0.2(P<0.008)$, and $0.3(P<0.002) \mathrm{kg} / \mathrm{d}$ greater for winter and summer in 1,2 , and $\geq 3$ parity, respectively. Cumulative fat yields were $9(P<0.001), 4(P<0.001)$, and $6(P<0.001)$ $\mathrm{kg} / 305 \mathrm{~d}$ for winter versus summer in parities 1,2 , and $\geq 3$, respectively.

\section{Survival}

The odds (95\% CI) of survival to a second calving for cows conceived in winter were $1.21(1.18-1.25)$ times the odds of survival for cows conceived in summer. When the PA of productive life was added to the model (model B), the odds (95\% CI) of survival to a second calving for cows conceived in winter were 1.15

Table 4. Least squares means (SE) for reproductive variables by season of conception (model B) ${ }^{1}$

\begin{tabular}{|c|c|c|c|c|c|c|c|c|c|}
\hline Performance variable & \multicolumn{3}{|c|}{ Parity 1} & \multicolumn{3}{|c|}{ Parity 2} & \multicolumn{3}{|c|}{ Parity $\geq 3$} \\
\hline Conceived in summer & 175 & 2.65 & & 158 & 2.25 & & 139 & 3.21 & \\
\hline \multicolumn{10}{|l|}{ Days to conception } \\
\hline Conceived in winter & 180 & 2.48 & $<0.001$ & 179 & 2.40 & 0.005 & 169 & 3.54 & 0.46 \\
\hline
\end{tabular}

${ }^{1}$ Cows $(\mathrm{n}=89,748)$ with parent average genetics information available. 
Table 5. Least squares means (SE) of milk production and milk fat yield by season of conception (model A)

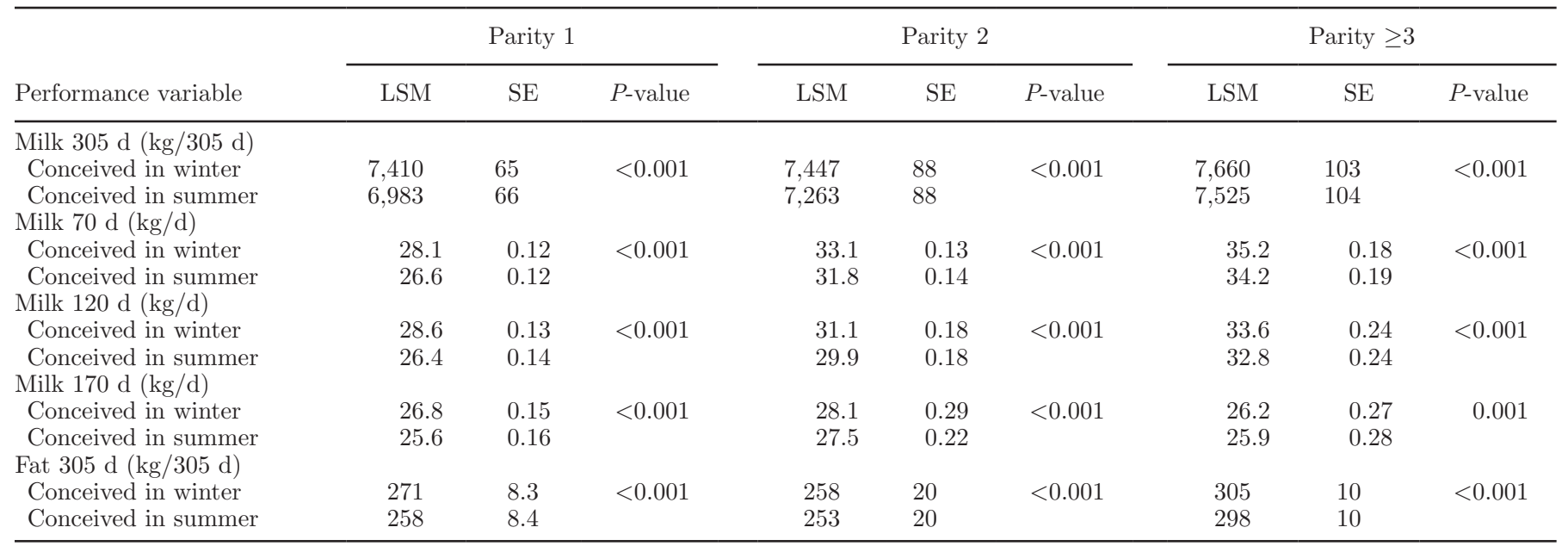

${ }^{1}$ Complete population of cows conceived in summer and winter $(\mathrm{n}=337,529$ lactation records).

(1.10-1.20) times the odds of survival for cows conceived in summer.

\section{DISCUSSION}

The objective of our study was to test the hypothesis that heat stress conditions associated with the season of conception and during the initial stages of embryonic development would have a life-long effect on survival and performance after birth as adult cows. The assumption that the summer season in Florida is characterized by climatic conditions that result in heat stress is in agreement with THI values calculated per calendar month. However, a potential role in the reported effects for other conditions associated with summer season is possible.

Data recorded from 152 Florida dairy herds enrolled in the DHI program provided the opportunity to in- vestigate the effect of summer heat stress as a maternal environmental stressor that affects substantial populations of dairy cows in the world. Our results showed that cows conceived in winter had, on average, better survival, better reproduction, and greater milk production than cows conceived in summer. Exceptions to this general trend are days to first breeding and days to conception in parity 3 , both for models $\mathrm{A}$ and $\mathrm{B}$.

We faced 2 main challenges for testing these associations in the present study. The first was properly differentiating herds according to the level of heat stress during the summer, and the second was isolating the effect of similar environmental conditions after time of conception until the first calving for cohorts of cows sharing their month of conception. Differences in performance could then be attributed to season of conception with confidence.

Table 6. Least squares means (SE) of milk production and milk fat yield by season of conception (model B) ${ }^{1}$

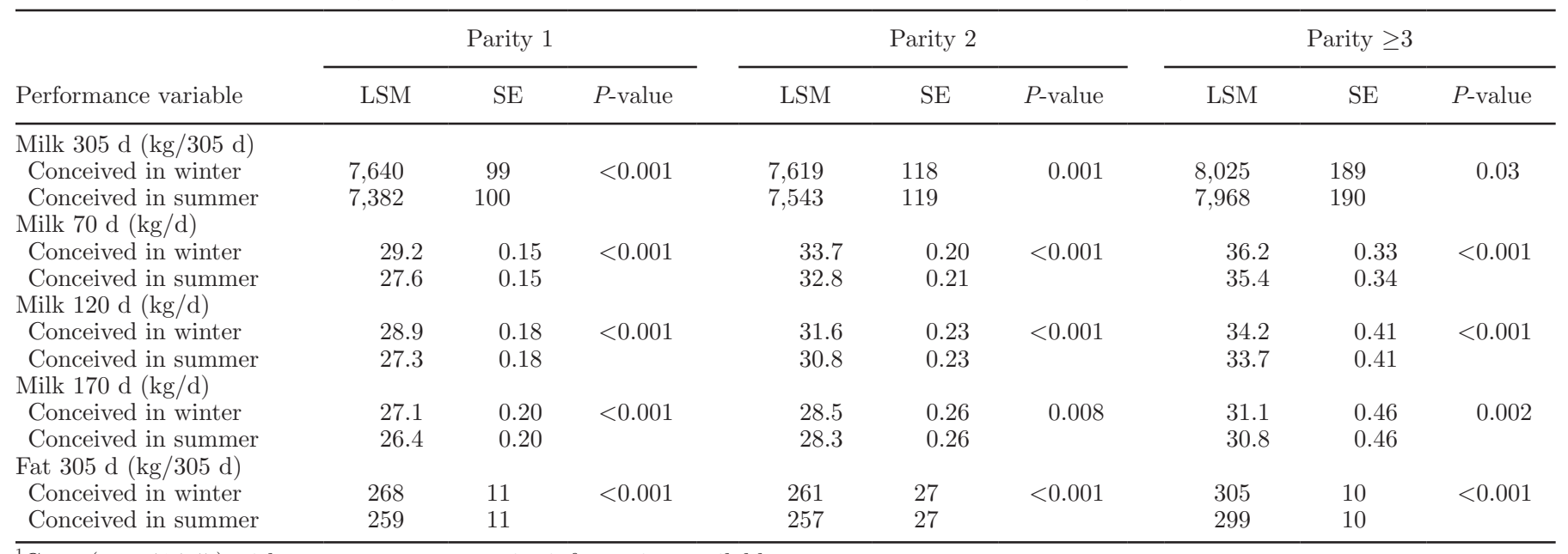

${ }^{1}$ Cows $(\mathrm{n}=41,747)$ with parent-average genetics information available. 
To overcome the first challenge, we created the seasonality index evaluating the magnitude of heat stress in each herd. Subsequently, this variable was forced into the models to account for the fact that cows maintained in herds with a high seasonality index were more likely to suffer from heat stress during summer. The THI data showed that in the winter there was generally no heat stress in Florida. The THI in the summer indicated near constant outside heat stress conditions. We did not have data on cooling, such as through fans and sprinklers, to measure the micro climate around the cows.

To overcome the second challenge of confounding, all results were adjusted for month of calving to remove seasonal effects other than month of conception as much as possible. The effect of summer heat after birth on calf health has been well documented and earlier work was reviewed by West (2003). For example, Donovan et al. (1986) observed that serum total protein concentration were lower in calves born during summer months in Florida. Similarly, season of birth was a significant variable affecting heifer growth (height and weight) during early life (Donovan et al., 1998). However, in our study, calves conceived during summer were born in the spring and were not exposed to severe heat stress during their first month of life.

The immediate effects of heat stress on cow performance and health is well recognized (Jordan, 2003; West, 2003). Even cows exposed to heat stress during their dry period had decreased milk production in the subsequent lactation and compromised immune function in the transition period (do Amaral et al., 2010, 2011; Tao et al., 2011, 2012b). Therefore, because month of first calving would likely be strongly associated with month of conception (Table 2), month and year of calving, age at first calving, and herd were included in the models to account for the effect of similar environment at the first calving in cohorts of cows.

Cows conceived in summer experienced summer heat stress 1 yr later as 3-mo-old calves and again 1 yr later as 15-mo-old heifers. Average level of heat stress during these times would be similar to heat stress at time of conception. Cows conceived in winter would experience heat stress approximately 6 mo after conception, and again around 9 and 21 mo after birth. We could not control for these differences in timing of heat stress with our models. Cows first calved approximately $3 \mathrm{yr}$ after the time they were conceived. The amount of heat stress from time of conception to first calving would be approximately similar for cows conceived in winter or summer. Our results indicate an association between differences in heat stress at the time of conception and the animal's adult performance; however, controlled experiments that expose animals to heat stress at dif- ferent times between date of conception and calving would elicit these temporal effects of heat stress on future performance.

Approximately one third of the cows in our study were the offspring of heifers. Heat stress may affect the offspring of heifers less than the offspring of cows, but we could not identify the parity of the mother at time of conception. Nor do we know if heifers in more seasonal herds experienced more heat stress than heifers in less seasonal herds. In Florida, heifers are generally kept outside with access to shade only, but many are also raised out of state in cooler regions. Therefore, the average cow is likely less affected by summer heat stress at time of conception if the mother was a heifer compared with a cow.

Another issue was the potential for differences in genetic merit in cows that were conceived in winter versus summer. Because reproductive performance of lactating cows is greatly reduced during thermal stress, as follicular dynamics are altered and oocyte quality is reduced (Collier et al., 2006), some dairy farmers modify their breeding strategies during parts of the year in areas such as Florida (Du, 2013). One of these strategies is the use of lower-cost semen in summer due to an expected decrease in probability of conception. As expected, PA for milk, fat, protein, productive life, and net merit were higher in cows conceived in winter. Surprisingly, PA for daughter pregnancy rate were higher in cows conceived in summer. Consequently, we included cows' PA as covariates in the analyses with model B. Results for model B were similar but smaller to those for model A, which suggests that the lower performance of cows conceived in summer cannot be completely explained by use of lower quality genetics in summer breedings.

Interestingly, the odds of survival to a second calving for cows conceived during winter were 1.19 times the odds of survival for cows that were conceived in summer. Plausible explanations for these differences in performance and survival include diverse intrauterine conditions affecting embryo development but also potential epigenetic effects. Experimental studies using animal models have shown that maternal nutrition during different stages of pregnancy can induce permanent changes in the structure, physiology, immune function, and metabolism of the offspring (Wu et al., 2006; Chmurzynska, 2010; Lan et al., 2013; Peñagaricano et al., 2013).

Our results indicated that age at first calving, time from calving to first breeding, and time to conception were consistently greater for cows that had been conceived during summer. These effects were more pronounced among first-parity cows compared with older cows. A potential explanation could be that the 
exposure to environment, as well as beneficial and detrimental events (disease, nutritional restrictions, and so on), during life may conceal the effect of heat stressors during conception. It is also interesting to note that second and greater calvings have a more even distribution across months (Table 2) than first calving. Although month of calving was included in the models, this may contribute to the reduction in the differences between cows conceived in different seasons when the number lactations increases.

Contrary to reported effects of heat stress during late gestation on offspring health and performance (Tao et al., 2012a, 2014), where a physiological effect on the highly demanding fetus is hypothesized, our study provided some evidence that, at time of conception, heat stress altered epigenetic processes that may affect the early embryo. Epigenetics is now commonly thought to represent a critical connection between gene expression and the environment, contributing to sustained changes in cellular phenotypes that are acquired during development (Petronis, 2010). Epidemiologic studies about maternal nutrition and effects on offspring's fertility are rare, but a link between impaired fetal growth, possibly caused by maternal malnutrition, and reproductive function has been established (Dupont et al., 2012). In a study by Sullivan et al. (2009), heifers were fed a low-protein diet during the first or second trimester of pregnancy. The largest prepubertal follicle was smaller in their female offspring compared with controls. Moreover, the female offspring had reduced densities of primordial and primary follicles and healthy antral follicles.

Milk production was significantly greater in cows conceived in winter, and this difference was more marked in first-parity cows. In agreement with our findings, Brown et al. (2015) reported that cows that were conceived during winter had an advantage in milk production over cows conceived in summer that ranged between 82 and $399 \mathrm{~kg}$ /lactation. The potential of epigenetic regulation to manipulate mammary function has been reported (Singh et al., 2010, 2012). A recent study tested maternal-related circumstances potentially associated with offspring performance. Females born to mothers that were lactating while pregnant produced $52 \mathrm{~kg}$ less milk, lived $16 \mathrm{~d}$ less, and were metabolically less efficient than females whose fetal life developed in the absence of maternal lactation (González-Recio et al., 2012). Gudex et al. (2014) investigated whether the prenatal maternal environment in dairy cattle influences the postnatal milking performance of the resulting daughters and grand-daughters. Variation in the prenatal environment was associated with a small but significant proportion of the total phenotypic variation in all traits in Holstein cows and in the first-lactation milk volume and milk protein and second-lactation milk fat in Jerseys.

Very early mammalian development is a crucial period for establishing and maintaining epigenetic marks (Heijmans et al., 2008); therefore, periconceptional exposure to stress may result in persistent changes in epigenetic marks that have life-long phenotypic consequences (Heijmans et al., 2008; González-Recio et al., 2012). These marks will result in unmethylated or hypomethylated $\mathrm{CpG}$ islands in promoters that are often associated with active transcription; conversely, hypermethylated DNA would suppress gene transcription (Tian, 2014). Remarkably, Peñagaricano et al. (2013) reported that supplementing methionine to dams before conception and during the preimplantation period can modulate gene expression in bovine blastocysts.

We report differences in the animal's adult performance that were associated with the season of conception. However, for some of the variables under analysis, these differences were moderate in size and the variation among individuals and operations is highly dependent on management practices. Further research may elicit the epigenetic effects of heat stress during the time of conception on future performance of the animal (offspring).

\section{CONCLUSIONS}

In conclusion, cows that were conceived in the winter had better subsequent reproduction, milk and fat production, and survival than cows conceived in the summer. These results provided some evidence that heat stress at the time of conception may alter epigenetic processes that might affect the early embryo. Further research to elucidate potential mechanisms associated with the effects reported in this study is anticipated.

\section{ACKNOWLEDGMENTS}

The authors thank Zoetis (Kalamazoo, MI) for financial support that partly funded this study. We also thank Dairy Records Management Systems (Raleigh, $\mathrm{NC}$ ), which supplied the DHI data in this study, and the Council for Dairy Cattle Breeding (Beltsville, MD), which supplied the genetics data. Fernanda C. Ferreira (Department of Animal Sciences, University of Florida) supplied the THI data.

\section{REFERENCES}

Arriola, K. G., and A. De Vries. 2016. Florida dairy industry statistics: Economic measures. Accessed Jan. 20, 2017. http://edis.ifas.ufl. edu/pdffiles/AN/AN28700.pdf.

Bach, A. 2012. Ruminant nutrition symposium. Optimizing performance of the offspring: Nourishing and managing the dam and 
postnatal calf for optimal lactation, reproduction, and immunity. J. Anim. Sci. 90:1835-1845.

Brown, B. M., J. W. Stallings, J. S. Clay, and M. L. Rhoads. 2016. Periconceptional heat stress of Holstein dams is associated with differences in daughter milk production and composition during multiple lactations. PLoS ONE 11:e0148234. https://doi. org/10.1371/journal.pone.0148234.

Bucklin, R. A., D. R. Bray, and D. K. Beede. 2015. Methods to relieve heat stress for Florida dairies. Accessed Jan. 18, 2017. https:// edis.ifas.ufl.edu/pdffiles/AE/AE02200.pdf.

Chmurzynska, A. 2010. Fetal programming: Link between early nutrition, DNA methylation, and complex diseases. Nutr. Rev. 68:8798.

Collier, R. J., G. E. Dahl, and M. J. VanBaale. 2006. Major advances associated with environmental effects on dairy cattle. J. Dairy Sci. $89: 1244-1253$

de Vries, A., and C. A. Risco. 2005. Trends and seasonality of reproductive performance in Florida and Georgia dairy herds from 1976 to 2002. J. Dairy Sci. 88:3155-3165.

do Amaral, B. C., E. E. Connor, S. Tao, M. J. Hayen, J. W. Bubolz, and G. E. Dahl. 2010. Heat stress abatement during the dry period influences prolactin signaling in lymphocytes. Domest. Anim. Endocrinol. 38:38-45.

do Amaral, B. C., E. E. Connor, S. Tao, M. J. Hayen, J. W. Bubolz, and G. E. Dahl. 2011. Heat stress abatement during the dry period influences metabolic gene expression and improves immune status in the transition period of dairy cows. J. Dairy Sci. 94:86-96.

Donovan, G. A., L. Badinga, R. J. Collier, C. J. Wilcox, and R. K. Braun. 1986. Factors influencing passive transfer in dairy calves. J. Dairy Sci. 69:754-759.

Donovan, G. A., I. R. Dohoo, D. M. Montgomery, and F. L. Bennett. 1998. Associations between passive immunity and morbidity and mortality in dairy heifers in Florida, USA. Prev. Vet. Med. 34:31-46.

Du, F. 2013. Characterization of pasture-based dairy farms in Florida and Georgia. MS Thesis. Department of Animal Sciences, Univ. Florida, Gainesville.

Dupont, C., A. G. Cordier, C. Junien, B. Mandon-Pépin, R. Levy, and P. Chavatte-Palmer. 2012. Maternal environment and the reproductive function of the offspring. Theriogenology 78:1405-1414.

Ferreira, F. C., R. S. Gennari, G. E. Dahl, and A. De Vries. 2016. Economic feasibility of cooling dry cows across the United States. J. Dairy Sci. 99:9931-9941.

Fleming, T. P., M. A. Velazquez, J. J. Eckert, E. S. Lucas, and A. J. Watkins. 2012. Nutrition of females during the peri-conceptional period and effects on foetal programming and health of offspring. Anim. Reprod. Sci. 130:193-197.

González-Recio, O., E. Ugarte, and A. Bach. 2012. Trans-generational effect of maternal lactation during pregnancy: a Holstein cow model. PLoS One 7:e51816.

Gudex, B., D. Johnson, and K. Singh. 2014. Prenatal maternal and possible transgenerational epigenetic effects on milk production. PLoS One 9:e98928.

Heijmans, B. T., E. W. Tobi, A. D. Stein, H. Putter, G. J. Blauw, E. S. Susser, P. E. Slagboom, and L. H. Lumey. 2008. Persistent epigenetic differences associated with prenatal exposure to famine in humans. Proc. Natl. Acad. Sci. USA 105:17046-17049.

Jordan, E. R. 2003. Effects of heat stress on reproduction. J. Dairy Sci. 86(Suppl.):E104-E114.

Lan, X., E. C. Cretney, J. Kropp, K. Khateeb, M. A. Berg, F. Peñagaricano, R. Magness, A. E. Radunz, and H. Khatib. 2013. Maternal diet during pregnancy induces gene expression and DNA methylation changes in fetal tissues in sheep. Front. Genet. 4:49.

Monteiro, A. P., S. Tao, I. M. Thompson, and G. E. Dahl. 2014. Effect of heat stress during late gestation on immune function and growth performance of calves: Isolation of altered colostral and calf factors. J. Dairy Sci. 97:6426-6439.

Peñagaricano, F., A. H. Souza, P. D. Carvalho, A. M. Driver, R. Gambra, J. Kropp, K. S. Hackbart, D. Luchini, R. D. Shaver, M. C. Wiltbank, and H. Khatib. 2013. Effect of maternal methionine supplementation on the transcriptome of bovine preimplantation embryos. PLoS One 8:e72302.

Petronis, A. 2010. Epigenetics as a unifying principle in the aetiology of complex traits and diseases. Nature 465:721-727.

Pinedo, P. J., and A. De Vries. 2010. Dynamics of culling risk with disposal codes reported by DHI dairy herds. J. Dairy Sci. 93:22502261.

Singh, K., R. A. Erdman, K. M. Swanson, A. J. Molenaar, N. J. Maqbool, T. T. Wheeler, J. A. Arias, E. C. Quinn-Walsh, and K. Stelwagen. 2010. Epigenetic regulation of milk production in dairy cows. J. Mammary Gland Biol. Neoplasia 15:101-112.

Singh, K., A. J. Molenaar, K. M. Swanson, B. Gudex, J. A. Arias, R. A. Erdman, and K. Stelwagen. 2012. Epigenetics: a possible role in acute and transgenerational regulation of dairy cow milk production. Animal 6:375-381.

St-Pierre, N. R., B. Cobanov, and G. Schnitkey. 2003. Economic losses from heat stress by US livestock industries. J. Dairy Sci. 86(Suppl.):E52-E77.

Stolwijk, A. M., H. Straatman, and G. A. Zielhuis. 1999. Studying seasonality by using sine and cosine functions in regression analysis. J. Epidemiol. Community Health 53:235-238.

Sullivan, T. M., G. C. Micke, R. M. Greer, H. F. Irving-Rodgers, R. J. Rodgers, and V. E. A. Perry. 2009. Dietary manipulation of Bos indicus $\mathrm{x}$ heifers during gestation affects the reproductive development of their heifer calves. Reprod. Fertil. Dev. 21:773-784.

Tao, S., J. W. Bubolz, B. C. do Amaral, I. M. Thompson, M. J. Hayen, S. E. Johnson, and G. E. Dahl. 2011. Effect of heat stress during the dry period on mammary gland development. J. Dairy Sci. 94:5976-5986.

Tao, S., and G. E. Dahl. 2013. Invited review: Heat stress effects during late gestation on dry cows and their calves. J. Dairy Sci. 96:4079-4093.

Tao, S., A. P. Monteiro, I. M. Thompson, M. J. Hayen, and G. E. Dahl. 2012a. Effect of late-gestation maternal heat stress on growth and immune function of dairy calves. J. Dairy Sci. 95:7128-7136.

Tao, S., A. P. A. Monteiro, M. J. Hayen, and G. E. Dahl. 2014. Short communication: Maternal heat stress during the dry period alters postnatal whole-body insulin response of calves. J. Dairy Sci. 97:897-901.

Tao, S., I. M. Thompson, A. P. A. Monteiro, M. J. Hayen, L. J. Young, and G. E. Dahl. 2012b. Effect of cooling heat-stressed dairy cows during the dry period on insulin response. J. Dairy Sci. 95:50355046.

Tian, X. C. 2014. Genomic imprinting in farm animals. Annu. Rev. Anim. Biosci. 2:23-40.

West, J. W. 2003. Effects of heat-stress on production in dairy cattle. J. Dairy Sci. 86:2131-2144.

Wood, P. D. P. 1967. Algebraic model of the lactation curve in cattle. Nature 216:164-165.

Wu, G., F. W. Bazer, J. M. Wallace, and T. E. Spencer. 2006. Boardinvited review: Intrauterine growth retardation: Implications for the animal sciences. J. Anim. Sci. 84:2316-2337.

Zimbelman, R. B., R. P. Rhoads, M. L. Rhoads, G. C. Duff, L. H. Baumgard, and R. J. Collier. 2009. A re-evaluation of the impact of temperature humidity index (THI) and black globe humidity index (BGHI) on milk production in high producing dairy cows. Pages 158-168 in Proc. Southwest Nutr. Man. Conf., Tempe, AZ. Univ. Arizona, Tuscon 